\title{
Research on Professional Index System of Applied Technology Universities in China
}

\author{
Qinglan Luo ${ }^{1, a^{*}}$, Chunyan Wang ${ }^{1, b^{*}}$ and Xin $\mathrm{Su}^{1, \mathrm{c}}$ \\ ${ }^{1}$ College of Business Administration, Jilin Engineering Normal University, Changchun, China \\ asunny203@126.com, b541012329@qq.com, ${ }^{\mathrm{c}} 328570200 @ q q . c o m$
}

${ }^{*}$ The corresponding author

Keywords: Application technology; Universities; Professional evaluation; Index system; Building

\begin{abstract}
The application technology universities developed after the technology universities union building in 2013. In the existing literature, the research about applied technology university is relatively a few, especially for the research about professional evaluation of application technology universities almost blank. There is not a set of complete and effective professional evaluation index system until now. Therefore, based on the analysis of the professional evaluation index system of university in foreign developed countries, this paper built evaluation index system of application technology universities from four aspects, what are professional position and characteristics, teaching staff, teaching construction, teaching effect and social evaluation. We hope it can provide evaluation standard and reference for construction of application technology universities.
\end{abstract}

\section{Introduction}

Since the universities enrollment expansion, Chinese higher education got unprecedented development. It not only satisfies the social demand, but also cultivates more talents for the society. Higher education plays an important role in the development of local economic and social and is paid attention by more and more people [1]. With the development of higher education in China, it is becoming the urgent problems about how to increase the teaching quality of higher education, improve the structure of talent training through professional setting and adjustment to serve for the local economy [2]. Therefore, based on the bottleneck in the developing of application technology university, this paper takes the professional evaluation as the research object of the application technology university, through the design of its index system, to help application technology university find its orientation, avoid the homogeneity development for comprehensive evaluation. And it can also help to avoid the disorientation, talents training target convergence, being short of the corresponding characteristics and advantages in the process of popularization. So that we can promote the application technology universities developing smoothly and orderly, help it transition successfully and give full play to the advantages and functions of all kinds of colleges and universities. This paper has profound significance whether for colleges' evaluation, the application technology development, and high quality applied talents cultivation, or for the government macro management and higher education development.

\section{Analysis on the Professional Evaluation Index System of Application Technology University in Developed Countries}

In general, professional evaluation system can be divided into three parts in western developed country [3], namely the university itself, intermediary organization, and government dominant assessment (showing in Fig. 1). University assessment means diagnosing and improving. Intermediary organization assessment means understand and supervision the university's evaluation process. Government assessment means guiding the direction of running and regulating the funds of assessment activities. Analyzing on the lesson of university professional evaluation in the developed countries 
experience, it is very useful for the construction of evaluation index system of application Technology University in China [4].

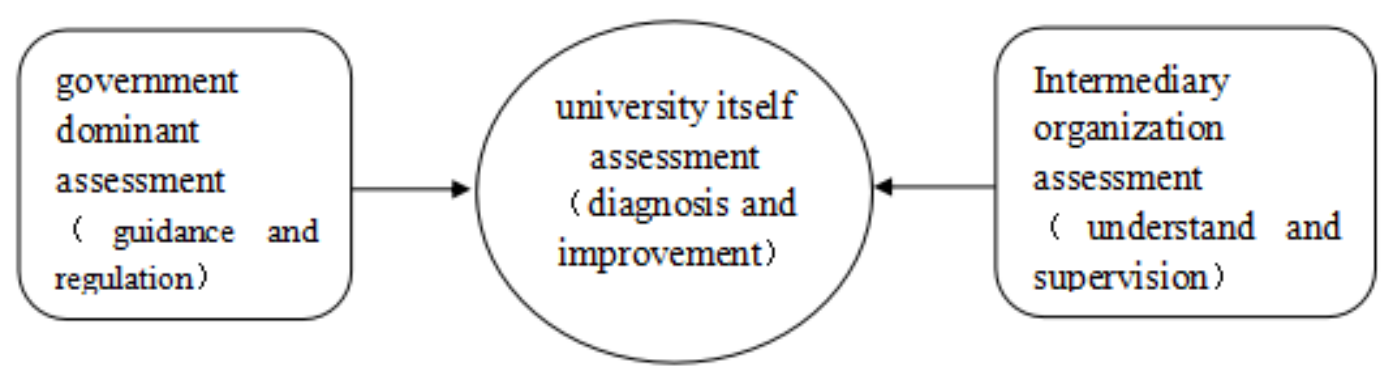

Figure 1. Higher education assessment main body and content of western developed countries

In some developed countries, application technology universities were established in the 1970s. It has been more than 30 years. applied technology university of, Han who is director of the center for Chinese higher education coming from German Osnabruck said, application technology university is a self-contained pillar in the German system of universities, the seven famous application technology universities building the elite league in German. One of vice-chancellors in Stenden University, Dai Hao said there are 70 percent of college students who study in vocational technical college in Holland. Community colleges of 24 states allow for vocational and technical education of undergraduate level in America. In Germany, Switzerland, Finland, the Netherlands and other countries which have more application technology universities, their competitive force are not only in the top of the world, but also the unemployment rates are low.

The first to evaluate is university in the United States. Its main evaluation index as: peer review, freshman admission standards, teacher resources, graduation rates and freshman retention, financial resources, alumni donations, graduate performance, etc. [5]. How to set the professional curriculum, formulate the curriculum standards and decide on procedures of assessment and quality assurance are traditionally depend on profession itself. Its index system mainly include: student satisfaction, research quality, enroll standards, and student-faculty ratios, services and equipment investment, students completion, the good academic reputation, graduate prospects[6]. In Finland, whether to participate in the evaluation is the autonomy of institutions of higher education. The assessment activities carried out on the basis of the principle of voluntary. In the specific assessment activities, according to its development plan institutions of higher education choose domestic or internationally recognized evaluation criteria [7].

\section{Design on the Professional Evaluation Index System of Application Technology University in China}

Evaluation Index System Design Process. In actual professional evaluation, it really needs to establish a scientific, comprehensive, and accurate evaluation index system, which is an important part [8]. The steps of evaluation index system are showing in Fig. 2.

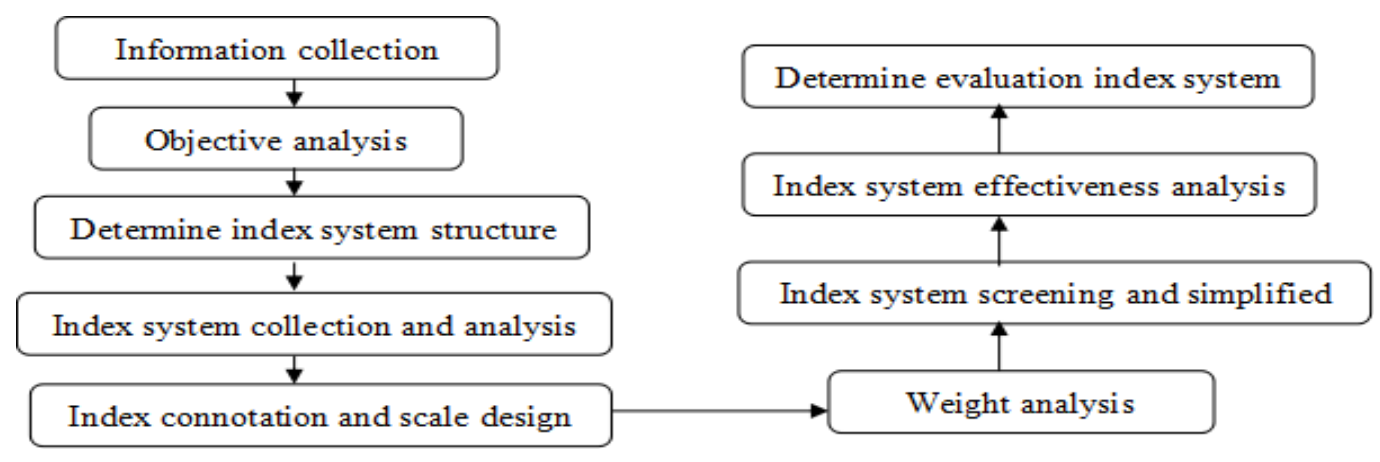

Figure 2. Design process of evaluation index system 
Evaluation Index System Design Content. Through the above analysis, the professional evaluation index system of application Technology University is established. It is shown in Table 1.

Table 1 Application technology university professional evaluation index system

\begin{tabular}{|c|c|c|c|c|c|c|}
\hline \multirow{2}{*}{$\begin{array}{l}\text { Level } \\
\text { indicators }\end{array}$} & \multirow{2}{*}{$\begin{array}{l}\text { Secondary } \\
\text { indicators }\end{array}$} & \multirow{2}{*}{ Evaluation standard } & \multicolumn{4}{|c|}{$\begin{array}{c}\text { Assessment } \\
\text { level }\end{array}$} \\
\hline & & & $\mathrm{A}$ & $\mathrm{B}$ & $\mathrm{C}$ & $\mathrm{D}$ \\
\hline \multirow{3}{*}{$\begin{array}{l}\text { Professional } \\
\text { orientation and } \\
\text { characteristics }\end{array}$} & $\begin{array}{l}\text { Talent training } \\
\text { target and } \\
\text { scheme }\end{array}$ & $\begin{array}{l}\text { Reflecting "application" on the training goal, and } \\
\text { "jobs" in the talent training scheme. }\end{array}$ & & & & \\
\hline & $\begin{array}{c}\text { Professional } \\
\text { orientation }\end{array}$ & $\begin{array}{l}\text { Profession adapts to the need of regional economic } \\
\text { and social development, and building an innovative } \\
\text { country, develops urgent talents of enterprise and } \\
\text { industry. }\end{array}$ & & & & \\
\hline & $\begin{array}{l}\text { Professional } \\
\text { characteristics }\end{array}$ & $\begin{array}{l}\text { Profession obtains outstanding outcome on talent } \\
\text { training mode, curriculum provision, or } \\
\text { university-industry cooperation [8]. }\end{array}$ & & & & \\
\hline \multirow{5}{*}{$\begin{array}{l}\text { Teachers' } \\
\text { team }\end{array}$} & $\begin{array}{l}\text { Professional } \\
\text { director }\end{array}$ & $\begin{array}{l}\text { Professional director } \\
\text { a high professional title, more scientific payoffs, } \\
\text { high academic level and the strong ability of practice } \\
\text { guidance. }\end{array}$ & & & & \\
\hline & $\begin{array}{l}\text { Teachers' } \\
\text { configuration } \\
\text { and structure }\end{array}$ & $\begin{array}{l}\text { Professional teachers' quality is higher, } \\
\text { who's proportion of } 30 \% \text { or more teachers from } \\
\text { enterprise full-time or part time [9]. Theory and } \\
\text { practice of guiding teacher ratio is } 1.5: 1 \text {, with one } \\
\text { teaching masters. The teachers have the master's } \\
\text { degree are in a proportion of } 80 \% \text { or more. } \\
\text { Associate professors (or senior engineers) are } 70 \% \\
\text { above title, age structure (under the } 55 \text { years old } \\
\text { teachers accounted for } 85 \% \text { or higher). }\end{array}$ & & & & \\
\hline & $\begin{array}{l}\text { Teaching } \\
\text { ability and } \\
\text { level }\end{array}$ & $\begin{array}{l}\text { Obtaining teaching prizes more than two at the } \\
\text { provincial level or above. Students are satisfied with } \\
\text { the professional teachers (excellent and good rate of } \\
90 \% \text { or higher).there are one teacher using foreign } \\
\text { language and two teachers using double language to } \\
\text { have class. }\end{array}$ & & & & \\
\hline & $\begin{array}{l}\text { Industry-unive } \\
\text { rsity-research }\end{array}$ & $\begin{array}{l}\text { Scientific research promoting teaching } \\
\text { achievements, and closely linking to social practices. } \\
\text { scientific research funds (science and engineering, } \\
\text { agriculture, medical profession) per } \\
\text { capita 30000RMB per year, Other profession per } \\
\text { capita 10000RMB per year. }\end{array}$ & & & & \\
\hline & $\begin{array}{l}\text { Teacher } \\
\text { training }\end{array}$ & $\begin{array}{l}\text { Have teachers' introduction, training plan and } \\
\text { measures conforming to the professional } \\
\text { construction planning. }\end{array}$ & & & & \\
\hline $\begin{array}{l}\text { Teaching } \\
\text { Tableblasint. } \\
\text { construction }\end{array}$ & $\begin{array}{l}\text { Teaching } \\
\text { equipment and } \\
\text { condition }\end{array}$ & $\begin{array}{l}\text { With characteristic experiment (training) room } \\
\text { (such as foundation, teaching, research laboratory), } \\
\text { college students' innovative business } \\
\text { incubators. Each teaching special funds is } \\
\text { enough and sustainable growth. }\end{array}$ & & & & \\
\hline
\end{tabular}




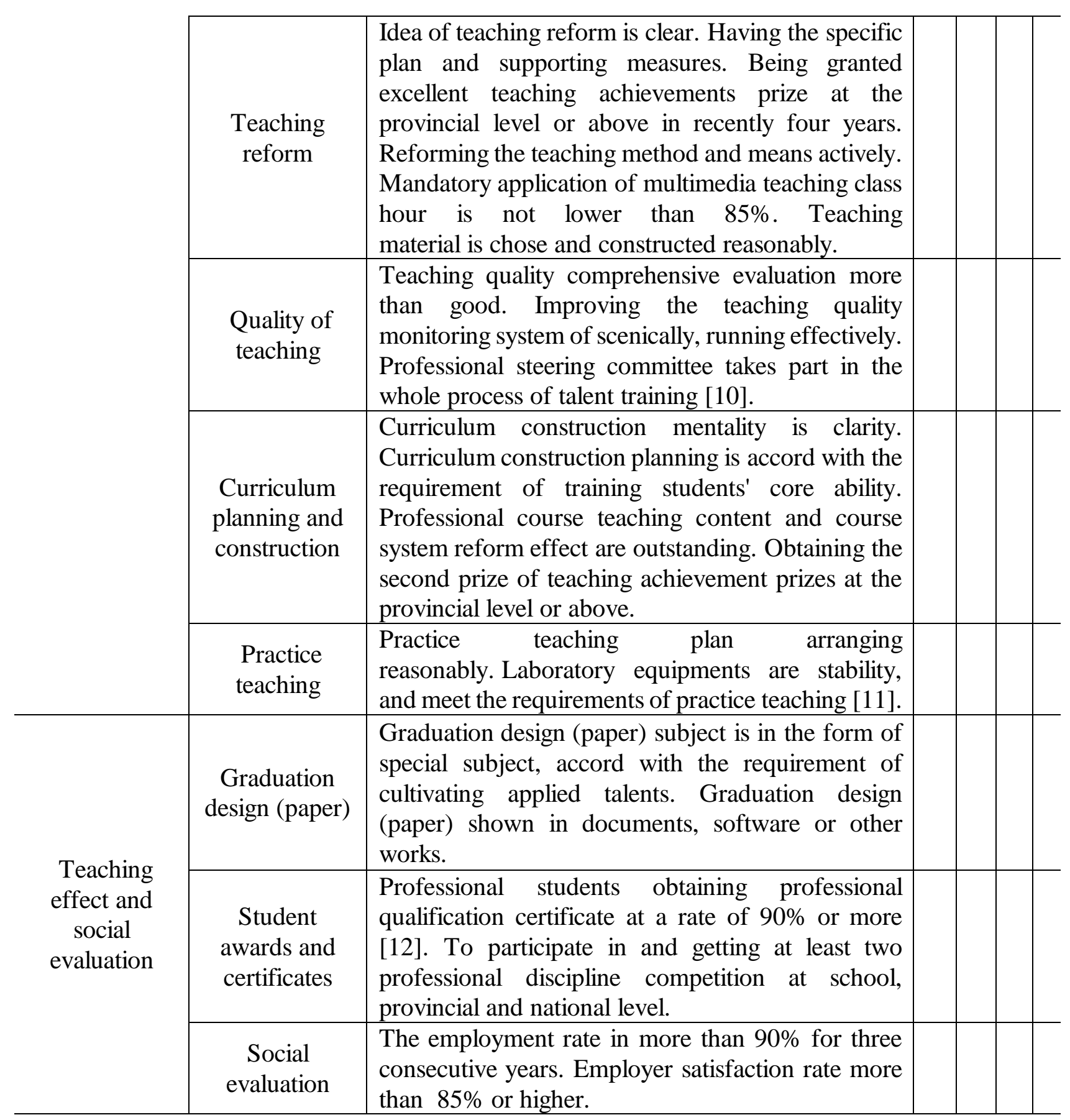

Remarks. The index system has 4 level indicators and 17 secondary indicators, for each secondary indicator divided into four assessment level what are A, B, C, D. The evaluation outcome has four standards what are excellent, good, qualified and unqualified, as follows:

Excellent: A has 13 or higher, $\mathrm{C}$ has 2 or less, $\mathrm{D}=0$.

Good: A and B together have 13 or higher, D has 1 or less. Qualification: D has 3 or less.

\section{Conclusions}

To design and construct the application technology universities professional evaluation index system, it is not only useful for strengthening the construction of local colleges and applied talents training, but also providing standard for the government to improve the macro management of the application technology universities. It is advantageous to develop reasonably for the application technology universities under the government's guidance, and provide intellectual and talent support for the 
development of the economic society and all walks of life. Therefore, this paper has profound significance whether for colleges' evaluation and the application technology profession development, or for the teachers' team building and talent training mode innovation.

\section{Acknowledgements}

This paper is the one of achievements of "Research on design and application of professional evaluation index system in the development of the local colleges transformation" and financially supported by Jilin Provincial Education Department ([2016] No. 32)

\section{References}

[1] Information on http://www.gov.cn/ldhd/htm

[2] Y.C. Chen: Research on Evaluation Standards and Index System of Professional Colleges (MS., Hunan University, China 2013), p.5.

[3] R.L. Linn and N.E. Gronlund: Measurement and Assessment in Teaching (8 ${ }^{\text {th }}$ Edition) (Trans China Light Industry Press, China 2003).

[4] Y.H. Gao: International Comparison of Higher Education and Its curriculum and Development Model ( Jangsu University Press, China 2011).

[5] L. Dicks and D. Taylor: Adults Learning, (2005) No.16, p.26-27.

[6] J. Valimaa and M. Mollis: Higher Education in Europe, Vol.29 (2004) No.1, p.67-86.

[7] M. Carpenter: Concepts \& Transformation, Vol. 9 (2004) No.3, p.305-310.

[8] W.J. Qiu, G. Zhao and W. Lei: Research in Higher Education of Engineering, Vol. 34 (2016) No.6, p.138-143.

[9] Y.J. Sun, J.J. Dou, Q.Q. Wang and F. Jiang: China Training, Vol. 23 (2016) No.4, p.153.

[10] Q. Zheng, W.Z. Wang, W.F. Zhao and Y.Y. Hu: Higher Education Exploration, Vol. 32 (2016) No.12, p.36-40.

[11] C. Chen, S.Z. Li and X. Pei: Journal of Yangtze University (Social Sciences Edition), Vol. 36 (2014) No.4, p.160-162.

[12] H. Li: China Electric Power Education, Vol. 30 (2014) No.9, p.30-31. 